\title{
Vancouver's supervised injection facility challenges Canada's drug laws
}

\author{
Kathleen Dooling MD MPH, Michael Rachlis MD LLD
}

Previously published at www.cmaj.ca

$\mathrm{H}$ arm reduction for injection drug users started with community-based programs to provide clean needles and has grown to include supervised injection facilities. Such services have existed for several years in Australia and Europe. ${ }^{1}$ In 2003, North America's first sanctioned supervised injection facility, Insite, was opened in the Downtown Eastside of Vancouver, British Columbia. To permit the facility to open, the then Canadian Liberal government exempted Insite from some provisions of the Controlled Drugs and Substances Act relating to trafficking.

In 2006, a Conservative government was elected. It eliminated harm reduction as a pillar of Canada's antidrug policy and began to threaten Insite with suspension of the federal exemption. In this article, we examine the role of scientific evidence and how a clash of values about harm reduction eventually led to two courts in the province of British Columbia to decide in favour of Insite and possibly other controversial forms of harm reduction, such as supervised inhalation. The federal government is appealing the case to the Supreme Court of Canada.

\section{Why Vancouver?}

Addiction problems in Vancouver's Downtown Eastside date back to the early days of logging in the city, when the neighbourhood around East Hastings Street became a refuge for unemployed men. ${ }^{2}$ Single men who could no longer work were drawn in by the neighbourhood's cheap housing and cheap liquor. In the 1960s, heroin and later crack cocaine joined alcohol as common substances of abuse. The commercial base of the Downtown Eastside relocated. ${ }^{3}$ The housing that remained was predominantly single-room occupancy hotels that offered communal toilet facilities and little in the way of facilities for cooking or food preparation.

Other factors have also contributed to Vancouver's concentration of people with addictions. A disproportionate number of residents are Aboriginal people,${ }^{4}$ many reeling from unhappy lives on unhealthy reserves. The city's relatively warm climate has attracted many people with addictions from other provinces. ${ }^{4}$ Finally, Vancouver is a major Pacific port, through which substantial quantities of illicit drugs pass. ${ }^{5}$

\section{The formation of coalitions}

Deaths from illicit drug use surged from 39 in 1988 to 357 in 1993 (Figure 1). ${ }^{6}$ More than half of the deaths were in Vancouver, which had less than $14 \%$ of the province's population.

\section{Key points}

- Research suggests that medically supervised injection of illicit drugs reduces needle-sharing and deaths from overdose and improves public order and uptake of addiction treatment.

- Two courts in the province of British Columbia have upheld the constitutional legality of supervised injection at Vancouver's Insite facility.

- The federal government remains politically opposed to Insite and is appealing the case to the Supreme Court of Canada.

Ninety percent of the deaths were associated with heroin, twothirds of the time in combination with alcohol and other drugs. By 1993, use of illicit drugs was the leading cause of death in British Columbia among men and women aged 15-44 years. ${ }^{6}$

This epidemic of overdose-related deaths prompted the creation of a task force led by the province's then chief coroner Vincent Cain. Cain's report called on government to pursue a course of legalization and decriminalization as part of an overall antidrug strategy. ${ }^{6}$

While the chief coroner's report garnered attention in government, the residents of the Downtown Eastside were organizing in the streets. In 1997, the Vancouver Area of Network Drug Users was formed to advocate for drug users. ${ }^{7}$ Its vision included a supervised injection facility.

In September 1997, Dr. John Blatherwick, then chief medical health officer of Vancouver, declared a public health emergency in the Downtown Eastside. ${ }^{8}$ At that time, overdose-related deaths were increasing after a temporary dip, but HIV infection rates were actually decreasing (Figures 1 and 2). In 1998, Dr. John Millar, the then provincial health officer for British Columbia, tabled a report that called for implementation of widespread harm reduction initiatives. ${ }^{9}$ By this time, the Vancouver Health Authority was contributing financially to the Vancouver Area of Network Drug Users, the Portland Hotel Society and a number of other community agencies. The harm reduction coalition had been born. ${ }^{10}$

The harm reduction coalition grew to include housing organizations, community service agencies, academics, journalists and some law enforcement officers. A bereaved parents group, "From Grief to Action," was particularly effective

Kathleen Dooling is Associate Medical Officer of Health, Peel Public Health, Peel, Ont. Michael Rachlis is an associate professor at the Dalla Lana School of Public Health, University of Toronto, Toronto, Ont.

CMAJ 2010. DOI:10.1503/cmaj.100032 
at highlighting that deaths were occurring across socioeconomic classes..$^{10}$ In 1999, Da Vinci's Inquest, a popular television series, served to further familiarize Canadians with the situation in the Downtown Eastside. The award-winning Canadian Broadcast Corporation production featured gruff Dominic Da Vinci as an ex narcotics cop turned Vancouver coroner who regularly dealt with preventable deaths on the drug-plagued streets of the Downtown Eastside.

In March 2000, the "Keeping the Doors Open" conference brought together politicians, academics, community members and law enforcement officials to discuss innovative approaches to harm reduction and served to cement connections between diverse groups that favoured harm reduction. ${ }^{10}$ Few opponents of harm reduction were in attendance.

In September 2000, the federal, provincial and municipal governments signed the Vancouver Agreement, which committed the signatories to work together toward urban renewal in Vancouver. The Vancouver Agreement identified harm reduction as one of four pillars of its antidrug strategy (the others were prevention, treatment/rehabilitation and enforcement.). ${ }^{3}$ In November 2000, the ruling Liberal party was reelected as the Canadian federal government, allowing them to follow through on the newly inked agreement.

The government had strong internal support for its position from four physician caucus members, two of whom were cabinet ministers during Insite's development and implementation. There was also strong support for Insite across the political spectrum in Vancouver and British Columbia. ${ }^{11}$

Harm reduction was not without opponents. In August 2000, the Community Alliance, comprised of local business and property owners in downtown Vancouver, voiced their opposition to all forms of harm reduction..$^{10}$ Not all members of the Vancouver police department were supportive of a supervised injection site, and the federal police force, the

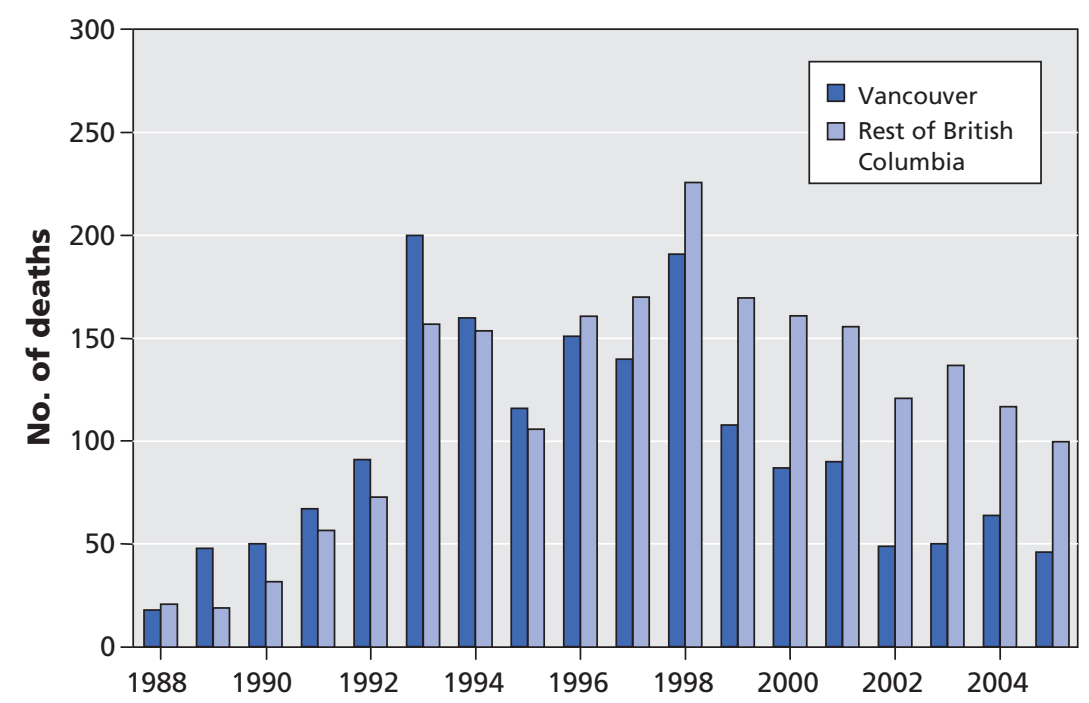

Figure 1: Deaths from the use of illegal drugs in the city of Vancouver and in the rest of the province of British Columbia, 1988-2005. Source: British Columbia Centre for Disease Control.
Royal Canadian Mounted Police (RCMP), was vehemently opposed. The business/police coalition organized a conference to challenge the tenets of harm reduction..$^{10}$ Supporters of harm reduction were not well represented, and thus no meaningful forum existed for open debate.

By 2002, the political landscape in Vancouver had fundamentally changed. Larry Campbell, the real-life model for the fictional crusading coroner Dominic Da Vinci, was elected mayor, with supervised injection a key part of his platform. Family members of addicts had attached a human face to addiction. In June 2003, the federal government granted permission to the Vancouver Coastal Health Authority, under Section 56 of the Controlled Drugs and Substances Act, to operate and evaluate a medically supervised injection facility. In September 2003, the Insite facility opened and was operating near capacity within weeks.

\section{Insite's effectiveness}

The objectives of Insite were clear: increase access to health care and addiction services, reduce overdose-related deaths, reduce transmission of blood-borne viral infections and other injection-related infections, and improve public order. ${ }^{12}$

The British Columbia Centre for Excellence in HIV/AIDS was commissioned to evaluate Insite. A study published in 2006 showed that there was an increase in uptake of detoxification services and addiction treatment. ${ }^{13}$ Another study published that year showed that Insite did not result in increased relapse among former drug users, nor was it a negative influence on those seeking to stop drug use. ${ }^{14}$ Results of studies using mathematical modelling showed that about one death from overdose was averted per year by Insite. ${ }^{1}$ A subsequent study estimated 2-12 deaths averted per year. ${ }^{15}$ Although these studies did not have sufficient power to detect any difference in incidence of blood-borne infections, Kerr and colleagues did find that Insite users were $70 \%$ less likely to report needle-sharing than those who did not use the facility. ${ }^{16}$ Before the opening of Insite, those same individuals reported needle-sharing that was on par with cohort averages. As for public order, Wood and colleagues found that there was no increase in crime following the opening of the facility. ${ }^{17}$ In fact, there had been statistically significant decreases in vehicle break-ins and theft, as well as decreases in injecting in public places and injection-related litter. ${ }^{17,18}$

In 2008, an economic analysis by Bayoumi and Zaric concluded that Insite provided incremental benefits beyond more traditional harm programs such as needle exchange. ${ }^{19}$ The investigators considered Insite's impact on needle-sharing behaviour, safe injection practices and increased referral to methadone maintenance treatment and concluded that there were incremental net savings of $\$ 18$ million and 1175 life-years over 10 years of facility operation. 


\section{Insite versus the new federal government}

Although scientific evidence of the benefits of Insite was mounting, the facility's future became uncertain when the Conservative Party replaced the Liberal Party as the Canadian federal government in January 2006. The Conservative's win was due mainly to voter reaction to a Liberal party corruption scandal, not a fundamental shift in Canadian values..$^{20}$ However, while campaigning, Conservative party leader Stephen Harper made his values clear: "We as a government will not use taxpayers' money to fund drug use."21

In August 2006, two national law enforcement organizations (the Canadian Police Association and the RCMP) requested that evaluation of Insite be halted and that no additional injection sites be established in other parts of Canada. ${ }^{22}$ Days later, then federal health minister Tony Clement announced that he would defer the decision to grant another federal drug exemption to Insite and was placing a moratorium on further sites in Canada. ${ }^{23}$ Clement stated that initial research had raised "new questions that must be answered." Yet the principle question he raised was whether supervised injection facilities contributed to lowering community drug use and fighting addiction. This was not one of Insite's original objectives. Moreover, given that Insite was operating near capacity and hosted less than $5 \%$ of injections taking place in the Downtown Eastside, ${ }^{1}$ it was unrealistic to expect a community-level impact on drug use.

Following Clement's announcement of a 16-month extension of Insite's exemption, he convened an expert advisory committee to examine existing research on supervised injection facilities. The committee was explicitly prohibited from making recommendations. Shortly thereafter, funding from Health Canada for the Insite research cohort was stopped..$^{22}$ In accordance with international drug control treaties that require ongoing scientific evaluation of exempted sites, the government opened a new research competition. However, the grant stipulated that recipients had to agree to refrain from disseminating their findings in any venue until the current exemption had expired. ${ }^{22}$ This "gag order" contravened several university codes of research ethics, and many academic research groups, including the BC Centre for Excellence in HIV/AIDS, were unable to compete for the grant.

Meanwhile, the RCMP was funding research of its own. Its first commissioned paper concluded that there were sound justifications for continuing the work at Insite. ${ }^{24}$ The RCMP distanced itself from this report and commissioned two others. Both subsequent reports were written by academic criminologists but were published in nonpeer-reviewed online journals. Both papers alleged that there were serious methodologic failings in the Insite research. ${ }^{25,26}$ One stated that there was no definitive evidence linking the facility to a reduction in blood-borne illness but gave only brief mention to the Disease Control. research by Kerr and colleagues that found significant reductions in needle-sharing by users of Insite..$^{25}$ The other report claimed that harm reduction had led to neglect of treatment programs but offered no substantiation for this claim. ${ }^{26}$

The Pivot Legal Society, under the Freedom of Information Act, later uncovered that the RCMP intentionally tried to cover up their connection with these reports. ${ }^{27}$ Once published, these reports were quoted frequently by the RCMP and Clement as justification for attempting to close Insite.

\section{Canada's new antidrug strategy}

In October 2007, Prime Minister Stephen Harper released the much anticipated National Anti-Drug Strategy. The plan pledged to end the "mixed messages" the Conservative government claimed had mired the previous government's drug policy. Noticeably absent from this new strategy was any reference to harm reduction..$^{28}$ The new message was clear: the four-pillar approach, endorsed by the World Health Organization (WHO) and numerous countries around the world, had lost a column.

In April 2008, the expert advisory committee convened by Clement reported on its findings. Thirteen of the 17 conclusions were positive, and none reported harmful or negative effects of Insite. ${ }^{1}$ The government chose to highlight the committee's conclusion that there was no evidence that Insite had influenced community-wide drug use or relapse. ${ }^{1}$ However, the basis of this conclusion, an evaluation of Insite, had not been powered to detect these differences even if they were present. Although the committee report stated that "[Insite] has contributed to an increased use of detoxification services and increased engagement in treatment," the lack of proof that Insite leads to abstinence continued to be used by opponents of the facility. Unfortunately, Bayoumi and Zaric's economic analysis ${ }^{19}$ was not available when the committee did its review.

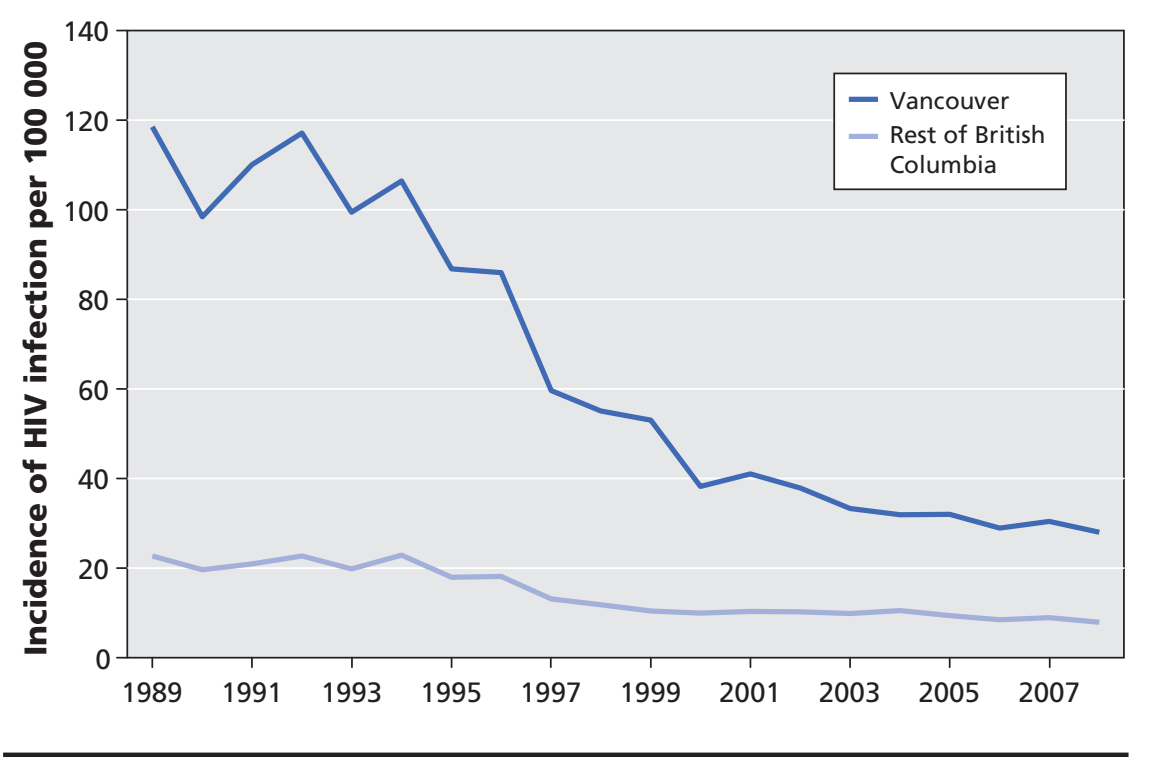

Figure 2: Incidence of HIV infection per 100000 in the city of Vancouver and the rest of the province of British Columbia, 1989-2005. Source: British Columbia Centre for 


\section{Insite on trial}

Canada's original constitution, the British North American Act of 1867, clarified the roles of the federal and provincial governments. Health care, including the regulation of health professions and hospitals, was designated exclusively under provincial jurisdiction. In the British tradition, there was originally no specific bill of rights. It was not until 1982 that then prime minister Pierre Trudeau championed the insertion of the Charter of Rights and Freedoms as clauses 1 through 34 of the Constitution Act of 1982. ${ }^{20}$

Canadian courts have not been reticent about using the Charter of Rights and Freedoms in cases on health. The first such case before the Supreme Court of Canada was in 1988. ${ }^{29}$ During the past two decades, Canadian courts have become somewhat more American, more likely to strike down laws passed by elected legislatures. ${ }^{30,31}$

In 2008, the Portland Hotel Society, a nonprofit organization that provides social housing and support to people with chronic substance abuse issues or concurrent disorders, went to court seeking to free Insite from federal control. On May 27, 2008, just one month before Insite's second exemption was to expire, British Columbia Supreme Court Judge Ian Pitfield handed down his verdict, finding that sections of the federal Controlled Drugs and Substances Act were inconsistent with Section 7 of the Charter of Rights and Freedoms, which states, "Everyone has the right to life, liberty and security of the person and the right not to be deprived thereof ...." Judge Pitfield further labelled Insite's services as health care, saying "While there is nothing to be said in favour of the injection of controlled substances that leads to addiction, there is much to be said against denying addicts health care services that will ameliorate the effects of their condition." He added "I cannot agree with the submission that an addict must feed his addiction in an unsafe environment when a safe environment that may lead to rehabilitation is the alternative." Insite remained open.

\section{Federal government defence of drug laws}

Within two days of Justice Pitfield's May 2008 verdict, then federal health minister Clement appeared before the House of Commons Standing Committee on Health and recommended appeal of the decision. ${ }^{32} \mathrm{He}$ stated that "Programs to support supervised injection divert valuable dollars away from treatment." However, Insite's \$3 million annual operating budget was a small sum compared to the $\$ 150$ million that Clement had pledged for treatment in the previous four months. ${ }^{28} \mathrm{In}$ fact, considering that $20 \%$ of visits to Insite were not for injection purposes and that the remaining visits often included counselling and wound care, the actual cost for supervised injection was well below the cited $\$ 14$ per injection. ${ }^{10}$ Finally, the Bayoumi economic analysis indicated that Insite's net economic benefits were significantly greater than its annual budget. ${ }^{19}$

On Aug. 4, 2008, while speaking at the XVII International AIDS Conference in Mexico City, Clement contradicted the WHO document he was introducing, stating "We believe [supervised injection] is a form of harm addition. ${ }^{{ }^{3} 3}$
In an Aug. 18, 2008, address to the Canadian Medical Association, Clement questioned the medical ethics of supervised injection, stating "The supervised injection site undercuts the ethic of medical practice and sets a debilitating example for all physicians and nurses, ... who might begin to question whether it's okay to allow someone to overdose under their care." ${ }^{3^{3}}$

Clement's comments outraged the Canadian medical and scientific communities. ${ }^{35}$ The Conservative government's position on harm reduction is, however, popular with its social conservative base. The Conservative caucus has no physician members and has repeatedly been criticized for its science policy. ${ }^{36,37}$

On Oct. 14, 2008, the Conservatives were re-elected. Plans for the appeal of the BC Supreme Court decision moved forward. The government asserted that, although the use of illicit drugs does pose a risk to life and security of the person, "these risks are attributable to the substances themselves and not to the laws prohibiting their possession and distribution." ${ }^{38}$ The appeal challenged Judge Pitfield's assertion that addicts are without free will with respect to their consumption, stating "If addicts were incapable of making a rational choice, no addict would ever be cured." According to the appellants, neither free will nor other barriers exist for addicts to minimize harm.

The territorial battle between the legislature and the judiciary, and between federal and provincial powers, over power to set public policy were brought to the fore on Jan. 15, 2010. In a $2-1$ ruling, the BC Court of Appeal maintained the lower court ruling. ${ }^{39}$ Writing for the majority, the Honourable Madam Justice Carol Huddart affirmed Justice Pitfield's use of Section 7 of the Charter of Rights and Freedoms and added the defence of jurisdictional immunity. Justice Huddart agreed with lawyers for the province and various Vancouver community services that Insite was a health care facility and was therefore under provincial jurisdiction.

On June 24, 2010, the Supreme Court of Canada granted the federal government leave to appeal the ruling. The court is expected to hear the case in the fall or winter of 2010.

\section{Beyond Insite}

A ruling by the Supreme Court of Canada will not only have ramifications across Canada but will also likely have an impact in the United States, which has taken an active role in debating Canadian drug issues. ${ }^{40} \mathrm{~A}$ review of the legal framework in the United States concluded that states and municipalities have some authority to regulate safe injection facilities, but federal agencies could supervene under the Controlled Substances Act. ${ }^{41}$ Local public health activists have investigated the establishment of safe injection facilities in San Francisco and New York City. ${ }^{42}$ There are no official facilities in the United States, but anecdotally, some agencies do informally provide safer environments for drug injection. ${ }^{42}$

Other countries are also watching the Canadian experience. As of 2009, there were 65 safe injection facilities operating in 27 cities in eight countries. ${ }^{42}$

Elsewhere in Canada, support for Insite has continued to grow. The Health Officers' Council of British Columbia 
passed a resolution in November 2008 recommending that supervised injection sites and other harm reduction services, including safe inhalation, be integrated with other health care services..$^{43}$ A similar resolution was passed in June 2009 by the National Specialty Society for Community Medicine, which represents Canadian public health physicians. ${ }^{44}$ In December 2009, the Quebec Public Health Agency recommended opening supervised injection facilities in that province. ${ }^{45}$ So far, no other jurisdiction has sought a federal exemption to establish a supervised injection or inhalation facility.

In the end, it will likely be the courts that determine the fate of Insite and of supervised injection in Canada.

This article has been peer reviewed.

Competing interests: None declared.

Contributors: Both authors contributed substantially to the writing and revising of the manuscript and approved the final version submitted for publication.

\section{REFERENCES}

1. Expert Advisory Committee. Vancouver's INSITE service and other supervised injection sites: What has been learned from research? Ottawa $(\mathrm{ON})$ : Health Canada. Available: www.hc-sc.gc.ca/ahc-asc/pubs/_sites-lieux/insite/index-eng .php (accessed 2008 Oct. 23)

2. Demolish city's skid road, murder protest demands. Vancouver Sun 1962 Apr. 6, p. 1 .

3. Four pillars drug strategy. Vancouver (BC): City of Vancouver; 2008. Available: http://vancouver.ca/fourpillars/factsheets.htm (accessed 2010 June 21).

4. McCreary Centre Society. No place to call home: a profile of street youth in British Columbia. Burnaby (BC): The Society; 2001.

5. Wood E, Tyndall MW, Spittal PM, et al. Impact of supply-side policies for control of illicit drugs in the face of the AIDS and overdose epidemics: investigation of a massive heroin seizure. CMAJ 2003;168:165-9.

6. Cain JV. Report of the Task Force into Illicit Narcotic Overdose Deaths in British Columbia. Burnaby (BC): Office of the Chief Coroner; 1994. p. 110.

7. Vancouver Area Network of Drug Users. About VANDU. Vancouver (BC): The Network. Available: www.vandu.org (accessed 2008 Oct. 8).

8. PHS Community Services Society v. Attorney General of Canada. (2008) BCSC 661. Available: www.courts.gov.bc.ca/Jdb-txt/SC/08/06/2008BCSC0661err1.htm (accessed 2010 Aug 18).

9. Millar JS. HIV, hepatitis, and injection drug use in British Columbia - Pay now or pay later? Victoria (BC): Office of Provincial Health Officer; 1998.

10. Small D, Palepu A, Tyndall MW. The establishment of North America's first state sanctioned supervised injection facility: a case study in culture change. Int $J$ Drug Policy 2006;17:73-82.

11. Mustel Group Market Research. BC residents support license extension for Vancouver's supervised injection site. Vancouver (BC): The Group; 2007. Available: www.mustelgroup.com/pdf/20070627.pdf (accessed 2009 Sept. 7).

12. Vancouver Coastal Health Authority. Insite - supervised injection site. Vancouver (BC): The Authority. Available: http://supervisedinjection.vch.ca (accessed 2010 June 21).

13. Wood E, Tyndall MW, Zhang R, et al. Attendance at supervised injecting facilities and use of detoxification services. N Engl J Med 2006;354:2512-4.

14. Kerr T, Stoltz J, Tyndall M, et al. Impact of a medically supervised safer injection facility on community drug use patterns: a before and after study. BMJ 2006;332: 220-2.

15. Milloy M, Kerr T, Tyndall MW, et al. Estimated drug overdose deaths averted by North America's first medically-supervised safer injection facility. PLoS One 2008;3:e3351.

16. Kerr T, Tyndall MW, Li K, et al. Safer injecting facility use and syringe sharing among injection drug users. Lancet 2005;366:316-8.

17. Wood E, Tyndall MW, Lai C, et al. Impact of a medically supervised safer injecting facility on drug dealing and other drug-related crime. Subst Abuse Treat Prev Policy 2006;1:13.

18. Wood E, Kerr T, Small W, et al. Changes in public order after the opening of a medically supervised safer injection facility for injection drug users. CMAJ 2004; 171:731-4.

19. Bayoumi AM, Zaric GS. The cost-effectiveness of Vancouver's supervised injection facility. CMAJ 2008;179:1143-51.

20. Brooks S. Canadian democracy: an introduction. Toronto (ON): Oxford University Press; 2007. p. 298-9.
21. No AIDS announcement during "politicized" week: Ottawa. Ottawa (ON): CBC News; 2006. Available: www.cbc.ca/canada/story/2006/08/17/safe-injection.html (accessed 2010 June 21).

22. Wood E, Kerr T, Tyndall MW, et al. The Canadian government's treatment of the scientific process and evidence: inside the evaluation of North America's first supervised injecting facility. Int J Drug Policy 2007;19: 220-5.

23. No new injection sites for addicts until questions answered says Minister Clement [news release]. Ottawa (ON): Health Canada; 2006 Sept. 1. Available: www .collectionscanada.gc.ca/archivesweb/20071121022930/http://www.hc-sc.gc.ca/ahc -asc/media/nr-cp/2006/2006_85_e.html (accessed 2010 Aug. 18).

24. BC injection site to continue operating, for now. Ottawa (ON): CBC News; 2006. Available: www.cbc.ca/canada/story/2006/09/01/injection-announcement.html (accessed 2010 June 21).

25. Davies G. A critical evaluation of the effects of safe injection facilities. J Global Drug Policy Practice 2007;1(3). Available: www.globaldrugpolicy.org/1/3/2.php (accessed 2010 June 21).

26. Mangham C. A critique of Canada's INSITE injection site and its parent philosophy: implications and recommendations for policy planning. J Global Drug Policy Practice 2007;1(2). Available: www.globaldrugpolicy.org/1/2/2.php (accessed 2010 June 21)

27. Complaint to Auditor General of Canada. Vancouver (BC): Pivot Legal Society; 2008. Available: www.pivotlegal.org/pdfs/RCMPsecretlyfundedreserch-documents .pdf (accessed 2010 June 21).

28. National anti-drug strategy. Ottawa (ON): Government of Canada; 2007. Available: www.nationalantidrugstrategy.gc.ca/nr-cp/doc2007_10_04.html (accessed 2010 June 21).

29. $R$ v. Morgentaler. (1988), 1 SCR 30

30. Jackman M. The implications of the Charter for health care spending in Canada. Ottawa (ON): Commission on the Future of Health Care in Canada; 2002. Available: http://dsp-psd.pwgsc.gc.ca/Collection/CP32-79-31-2002E.pdf (accessed 2010 June 21).

31. Canada. Debates of the Senate. No. 143-73 (21 Feb. 2007). Available: www.parl .gc.ca/39/1/parlbus/chambus/senate/DEB-E/pdf/073db_2007-02-21-e.pdf (accessed 2009 Apr. 6).

32. Standing Committee on Health. Standing Committee on Health on the subject of supervised injection sites. Ottawa (ON): Health Canada; 2008. Available: www.hc -sc.gc.ca/ahc-asc/minist/speeches-discours/2008_05_29-eng.php (accessed 2008 Oct. 18).

33. Clement's Insite attack leaves WHO red faced. Globe and Mail [Toronto] 2008 Aug. 6. Available: www.theglobeandmail.com/life/article701599.ece (accessed 2010 June 21)

34. Minister's speech before the Canadian Medical Association's annual general meeting. Ottawa (ON): Health Canada; 2008. Available: www.hc-sc.gc.ca/ahc-asc /minist/speeches-discours/2008_08_18-eng.php (accessed 2010 June 21).

35. Silversides A. Federal health minister assails ethics of Insite. CMAJ 2008;179:521.

36. Abraham C. Researchers fear stagnation under Tories. Globe and Mail. [Toronto] 2009 Mar. 2. Available: www.theglobeandmail.com/servlet/story/RTGAM .20090302.wresearch02/BNStory/National/home (accessed 2010 June 21.)

37. Canadian researchers call for end to "politicization" of science. Ottawa (ON): CBC News; 2008. Available: www.cbc.ca/technology/story/2008/10/09/scientistsletter.html (accessed 2010 June 21).

38. Factum of the Appellants: on appeal from the Supreme Court of British Columbia, from the order of the Honourable Mr. Justice Pitfield. Pronounced May 27, 2008; Vancouver, BC. File no. S065587 and S07554.

39. PHS Community Services Society v. Canada (Attorney General) (2010), BCCA 15.

40. US drug czar brings anti-drug message to Canada. Vancouver (BC): Vancouver Board of Trade; 2002. Available: www.boardoftrade.com/vbot_speech.asp?pageID $=174 \&$ speechID $=315 \&$ offset $=\&$ speechfind $=($ accessed 2010 June 21$)$

41. Beletsky L, Davis CS, Anderson E, Burris S. The law (and politics) of safe injection facilities in the United States. Am J Public Health 2008;98:231-7.

42. Smith P. Effort to bring safe injection facility to New York City getting underway. Drug War Chronicle 2009:587. Available: http://stopthedrugwar.org/chronicle 1587/campaign_safe_injection_facility_new_york_city (accessed 2010 June 21).

43. Martiquet P. Letter to health minister and health authorities. Vancouver (BC): Health Officers Council of British Columbia; 2008. Available: http://vancouver.ca /fourpillars/documents/Supervised_Injection_Services_HOC.pdf (accessed 2010 June 21).

44. National Specialty Society for Community Medicine. Supervised drug consumption sites and Insite Program. Ottawa (ON): The Society; 2009. Available: www.nsscm .ca/files/POSITION_ON_SUPERVISED_CONSUMPTION_SITES.pdf (accessed 2010 June 21).

45. Quebec Institute of Public Health. Avis sur la pertinence des services d'injection supervisée: analyse critique de la literature. Québec (QC): The Institute; 2009. Available: $w w w . i n s p q . q c . c a / p u b l i c a t i o n s / n o t i c e . a s p ? E=p \& N u m P u b l i c a t i o n=962$ (accessed 2010 June 21).

Correspondence to: Dr. Michael Rachlis, 13 Langley Ave., Toronto ON M4K 1B4; michaelrachlis@rogers.com 